\title{
A SURVEY OF THE PRACTICES OF THE APPROACHES TAUGHT IN AN INDUSTRIAL ENGINEERING UNDERGRADUATE PROGRAMME
}

\author{
K.A. Al-Ghamdi \\ Industrial Engineering Department \\ King Abdulaziz University, Saudi Arabia \\ kaaalghamdi@kau.edu.sa
}

\begin{abstract}
The Saudi labour market has recently witnessed intense competition between locallygraduated Industrial Engineers and those graduating from international universities. This has compelled local IE departments to find ways to improve the quality of their educational programmes and to ensure their alignment with the labour market's needs. To this end, insightful information can be obtained by contacting alumni and soliciting their perceptions of their education. However, empirical investigations based on this approach are rarely reported in the literature. To fill this gap, this study reports the results of a survey that was conducted to examine the gap between what is practised and what is taught in the Industrial Engineering (IE) programme at King Abdulaziz University (KAU). Apart from discussing the main characteristics of the alumni's employers, the study revealed that 'Engineering Economy' involves the most applied techniques in practice, whereas 'Engineering Management' incorporates the most applicable approaches. The limited use of IE techniques was mainly attributed to poor cooperation between practitioners and academics, and the simplistic nature of the problems addressed in the university curriculum compared with complex real-life ones. To deal with some of the identified problems, this paper argues for advisory board members to engage with industry when designing the curriculum, and for the adoption of problem-based learning.
\end{abstract}

\section{OPSOMMING}

Die Saoedi arbeidsmark ervaar deesdae intense kompetisie tussen plaaslike gegradueerde bedryfsingenieurs en bedryfsingenieurs van buitelandse universiteite. Dit het die plaaslike bedryfsingenieurswese departemente gedwing om van hul akademiese programme se standaarde te verbeter. Insiggewende inligting kan ingewin word deur alumni te kontak en na hul persepsies oor hulle akademiese opvoeding te vra. Empiriese ondersoeke op hierdie benadering gegrond word egter selde gepubliseer. Hierdie studie doen egter verslag oor die resultate van ' $\mathrm{n}$ peiling, wat bedoel is om die verskil tussen dit wat toegepas word in die industrie en dit wat onderrig word by die Koning Abdulaziz Universiteit, te bepaal. Die studie bespreek nie net die hoofeienskappe van die alumni se werkgewers nie, maar toon ook dat ingenieursekonomie die mees toegepaste tegnieke behels, terwyl ingenieursbestuur die mees toegepaste benaderings behels. Die beperkte gebruik van bedryfsingenieurswese tegnieke word hoofsaaklik toegeskryf aan swak samewerking van akademici en praktisyns en die eenvoudige aard van die probleme op universiteit aangeraak teenoor die ingewikkelde probleme in die industrie. Om sekere van hierdie geïdentifiseerde probleme aan te spreek word die adviesraadslede aangemoedig om meer in oorleg met die industrie die kurrikulum te ontwerp en om ' $n$ probleem georiënteerde leerplan aan te neem. 


\section{INTRODUCTION}

Industrial Engineering (IE) is the branch of engineering that focuses on the management and economic use of resources, products, and processes through the use of an arsenal of tools for strategic planning, optimisation, stochastic processes, modelling, quality engineering, information systems, work standards, safety, and human factors engineering [10].

In an effort to improve the education of future generations of Saudi students, the Saudi Ministry of Higher Education has launched a scholarship programme that aims to provide the country's labour market with an adequate supply of young graduates with excellent qualifications. Since its inception in 2005, the programme has provided more than 130,000 students with scholarships to pursue their undergraduate and postgraduate studies at the top universities in more than 30 countries. Since many of the scholarship recipients have already returned to Saudi Arabia with academic degrees in various disciplines, the competition between them and locally-graduated students has intensified. This is due to increased expectations on the part of employers, who desire high qualifications for entrylevel jobs and expect to appoint graduates who have developed a number of specific competencies during their time at university. Consequently, they intensify their screening process by preferring students who have credentials from elite institutions with high grades, or students with post-graduate qualifications.

IE has recently witnessed rapid growth and wide acceptance in the Saudi labour market. This, together with the intense competition in the labour market, has compelled local IE departments to find ways to improve the quality of their education programmes and to ensure their alignment with the labour market's needs and requirements. One approach that can offer insightful information about the quality of an educational programme is to contact its alumni and solicit their perceptions of their education. Empirical investigations based on this approach are rarely reported in the literature. To fill this void, this study adopted this approach to elicit responses from the IE department's alumni about facets of their education at King Abdulaziz University (KAU), and its alignment with the expectations and needs of the labour market. This study aims, therefore, to investigate the gap between what is practised and what is taught in the IE programme at KAU. Its objectives include:

1. Providing insights into the main employers of the department's alumni and their major characteristics;

2. Studying the extent to which the approaches and techniques taught in the IE programme are used in practice, and the degree of success in applying them;

3. Soliciting the perceptions of the department's alumni regarding the practical applicability of the taught techniques and approaches; and

4. Obtaining feedback from alumni about their satisfaction with their IE education, and the main obstacles to a wider use of the taught techniques and approaches.

After detailing the methodology applied in this study, the results are presented and discussed. The paper ends with its conclusions and main recommendations.

\section{METHODOLOGY}

The first stage of this study involved undertaking a comprehensive review of the IE curriculum at KAU, where the courses are classified into six categories:

1. Engineering Management

2. Engineering Economy

3. Quality Engineering and Statistics

4. Operations Research

5. J ob Design, Improvement and Safety

6. Computer Applications and Information Systems 
The courses under each of the categories above were thoroughly reviewed and the techniques and approaches taught in each course were extracted. A questionnaire was then compiled based on the study's objectives. A questionnaire method was selected because it is an inexpensive data collection approach that can produce quick results. Moreover, being quantifiable, its results can be statistically analysed, which allows the results from a sample to be generalised to a larger population [1]. The questionnaire was administered by means of structured interviews conducted by trained final year students, based on prearranged appointments with the participants.

\subsection{Survey design}

The questionnaire developed in this study has four main sections: the background of the employing company; the techniques used and degree of success (the extent to which the expected outcome of applying the technique was attained); perceived level of applicability in practice; and the level of satisfaction with IE education at KAU. The first section was intended to explore general information about the organisations in which the participants work, such as the size of the company, the type of industry, and whether any quality assurance system was adopted. As many of the IE techniques are generally incorporated into enterprise resource planning (ERP) and decision support systems, a question whether they had such systems was added. The second section consisted of a list of the 53 techniques and approaches that are currently taught in the IE department at KAU. These were classified into the previously-mentioned six categories. For each technique, the respondents were asked to rate their level of use, together with their degree of success in applying the technique, based on a five-point Likert scale ranging from 1 'very low' to 5 'very high'. For responses such as 'do not know' or 'not sure', a zero score was used. To collect data about the techniques used in practice but not taught in the IE programme, a question was added to ask the participants to identify these techniques.

The third section of the questionnaire aimed to collect data so that the six categories investigated - to which the examined IE techniques belong - could be ranked with respect to their applicability in practice. To accomplish this task, the analytic hierarchy process (AHP) was employed. Using this method, originally proposed by Saaty [8], the relative weights (importance) of pre-specified alternatives can be determined with respect to specific criteria [9]. In this study, applicability in practice was used as the criterion, and the six categories of IE techniques were regarded as the alternatives. The objective was to identify the practitioners' perception about the relative importance of each category with respect to practical applicability. This part of the questionnaire was thus designed based on the standard form of AHP questionnaires, which depend on pair-wise comparisons. As six categories were investigated, there were $15(6 ! /(2 !(6-2) !))$ possible pair-wise comparisons. For each of these, the participants were asked to express their preference for a specific category over another, with respect to practical applicability. To quantify the degree of preference, the numerical rating scales proposed by Saaty [9] were adopted.

As the pair-wise comparisons are based on personal or subjective judgments, some degree of inconsistency between the pair-wise comparisons may be observed. To deal with this possibility, consistency verification was conducted. This involved estimating a consistency ratio for each AHP questionnaire. Whenever this was found to exceed a threshold limit of 0.1 [9], the participant was asked to review and revise the pair-wise comparisons.

Having ensured the consistency of the individual pair-wise comparisons, they were aggregated to render an overall pair-wise comparison using the geometric mean. This was then viewed as a square matrix for which the eigenvector was obtained. The elements of this vector represent the preference weights of the examined categories in term of their practical applicability [8].

The last section of the questionnaire was intended to solicit information about the participants' perception of their satisfaction with the quality of their IE education, and the main barriers to applying the techniques learned in the undergraduate IE programme. A question about the approach that participants adopted in dealing with their practical 
problems was included. Moreover, for the techniques that are rarely used or not used, a list of possible causes was given. The participants were asked to rate their degree of agreement with each cause on a five-point Likert scale. They were also asked to add any cause(s) that they deemed important but could not find in the given list. Finally, an open question about the changes they would like to see in the current IE programme was posed.

To test the extent to which the items included in the questionnaire adequately cover the intended domain of the IE techniques and approaches taught in KAU, the questionnaire's content validity was assessed. This type of validity testing can be defined as the process of ensuring whether the domain of the concept that is desired to be measured is sufficiently captured by the content of the designed instrument [7]. Generally, it is not examined numerically but judged subjectively based on the opinion of experts. In this study, six senior IE faculty members participated in assessing the content validity of the questionnaire. Each of them is regarded as an expert in one of the six categories mentioned previously. Based on their feedback, the questionnaire was revised and redistributed to ensure its appropriateness. Its content was regarded as valid after the assessors reached consensus that the instrument included IE techniques that covered all aspects of the curriculum.

The targeted respondents for the survey were the students who graduated from the IE department at KAU during the period 2004-2010. Consequently, the minimum years of experience were about two, whereas the maximum was around eight. The choice of this period was based on the fact that these graduates had experienced the same five-year curriculum. The names and contact details of the department's graduates were obtained from the alumni database. The companies for which the targeted respondents work were located in the three major industrial zones in Saudi Arabia; the western, middle, and eastern provinces.

Six of the department's alumni were selected randomly from the database and invited to the department to participate in a pilot study. Their suggested amendments, which were mainly related to the questionnaire's format, were adopted. The final version of the questionnaire was then approved.

The questionnaires were distributed by a team of IE students in their final year of undergraduate studies at KAU. They were thoroughly trained so that they could answer any question that might be asked about the questionnaire's contents. In fact, several brainstorming sessions were held to explore possible queries arising from each question, and to agree upon the appropriate responses. The consistency of their performance in administering the questionnaire was confirmed in the pilot study that preceded the data collection stage. The main reason for adopting this approach was to ensure a full understanding of the survey's questions so that reliable information could be obtained. The participants were initially contacted by telephone, given an overview of the study and its objectives, and asked to participate. Appointments with those who agreed to participate in the study were then arranged. Accordingly, each participant was visited at their workplace by a member of the data collection team who was responsible for explaining the contents of the questionnaire to the participants and helping them to complete it.

\section{RESULTS AND DISCUSSION}

Generally, when a survey study is conducted, some candidate respondents will not agree to participate. The response rate is, therefore, regarded as an important indicator of the representativeness of the considered sample. This is because non-participants may differ in some significant characteristics from those who participate, thereby inflecting a response bias in the survey results. Non-participants also include those who agree to participate but answer very few questions, or exhibit clear evidence of not being serious in answering the posed questions [4]. 
A list of 242 names was prepared, including all the students who had graduated from the IE department during the 2004-2010 period. They were contacted by telephone and asked to participate. A total of 196 of them agreed to participate in the investigation, yielding a response rate of around 81 per cent. While there is no guarantee about constitutes a satisfactory response rate, there are some guidelines about acceptable rates. For example, response rates of around 80 per cent for face-to-face interviews, 70 per cent for telephone interviews, and 50 per cent for mailed questionnaires are generally regarded as adequate [2]. In the light of these guidelines, the response rate of 81 per cent was deemed acceptable.

In what follows, the results of the survey are presented and discussed, based on the four sections of the questionnaire.

\subsection{Companies' characteristics and profiles}

The main purpose of this section was to collect information about the main employers of the department's alumni. It transpired that the 196 participants were employed by 36 different companies. The implication was that, in some cases, many respondents were working for the same company. The major employers of the department's alumni were the Savola Group, Saudi Airlines, Saudi Electricity, the National Water Company (NWC), and the General Authority of Civil Aviation. About 69 per cent of the companies had more than 1,000 employees, indicating that the majority of the department's alumni work for large organisations. Moreover, 64 per cent of the employers were service organisations, reflecting the growing demand for Industrial Engineers in this sector. The areas of industry were diverse, with the food and beverages industry and the wholesale and retailing industry being the major sectors under the categories of manufacturing and service, respectively.

With regard to quality certification, ISO 9001:2008 was predominantly adopted by both the manufacturing (23.5 per cent) and services (38.2 per cent) employing organisations. Others certifications included the Hazard Analysis Critical Control Point (HACCP), the Saudi Arabia Standards Organisation (SASO), the National Institute of Occupational Safety \& Health (NIOSH), the Saudi Capital Market Authority (CMA), and some industry-related ISO certificates. These did not, however, feature very highly in the surveyed companies.

As for ERP systems, the survey revealed that they were used in 78 per cent of the organisations. Figure 1 depicts the main types of the implemented system. As can be seen, SAP was the most popular, followed by ORACLE. Furthermore, only 5 per cent of the organisations implemented the AS400 system, whereas 20 per cent used internallydeveloped applications.

\subsection{The levels of use of techniques, and degrees of success}

Participants were asked to indicate their level of use and success for each of the surveyed techniques on a scale from 1 to 5. Generally, the responses showed a low level of use and success, as the average score was less than 3 (Moderate) in five of the six groups (see Figure 2). In fact, the highest average level of use and success attained was 3, and was associated with the 'Engineering Economy' category. The 'Operations Research' group is characterised as having a very low level of use, with a score of around 1 . The difference observed between the groups' average levels of use was found to be significant in the Analysis of Variance (ANOVA). In fact, the p-value was 0.0001 , which was remarkably smaller than a $(=0.05)$.

Regarding the success in applying the six groups of IE techniques, it was noted that the differences between the levels of use and the degrees of success were only marginal. To assess this observation, a t-test was employed to see whether the difference was significant (as presented in Table 1 ). Clearly, none of the $p$-values was less than 0.05 , indicating the absence of significant differences between the compared means. Also revealed in Table 1 is the insignificant difference between the service and manufacturing sectors in respect of 


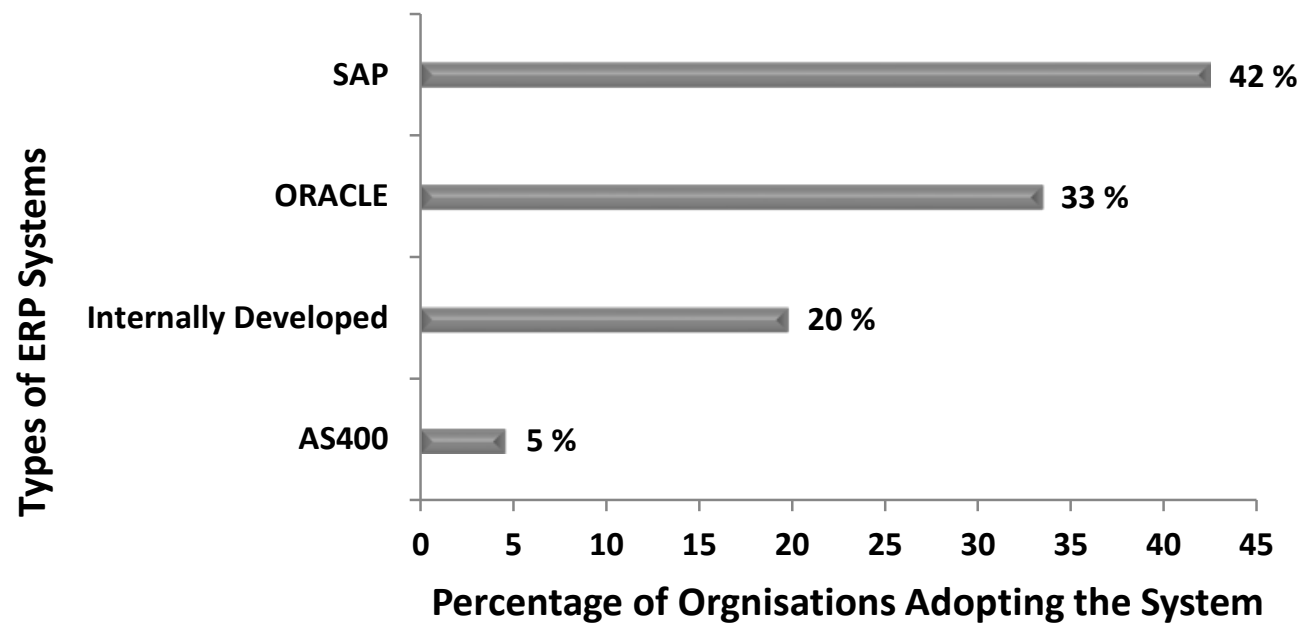

Figure 1: Distribution of the adopted ERP systems

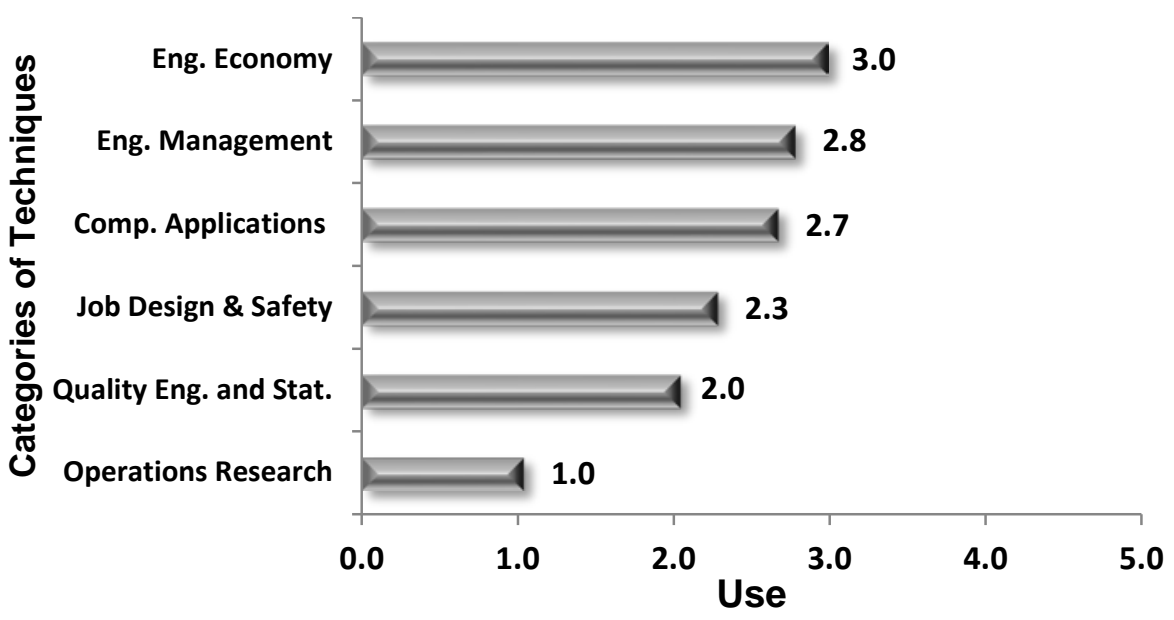

Figure 2: Average levels of use for each of the IE technique categories

the levels of using the six groups of techniques. Moreover, the null hypothesis - of no difference in the use of the six groups between the BSC and the MSc degree holders among the participants - was not rejected, as none of the rendered p-values was smaller than 0.05 . This implies that obtaining a master's degree in IE does not improve the level of using the IE techniques. The first position of the 'Engineering Economy' group is not surprising, considering that it involves such techniques as 'break even analysis', 'feasibility study', and 'benefit-cost analysis'.

The application of these techniques is a prerequisite for undertaking any project or improvement endeavour, and thus they are in high demand in practice. In fact, 62 per cent of the participants indicated a moderate to high level of use of these techniques, as their average score was greater than or equal to 3. Table 2 gives the techniques that belong to the 'Engineering Economy' category, together with their average levels of use. It can be noted that the six techniques attained a moderate level of use, with the 'feasibility study', 'benefit-cost analysis', and 'cash flow analysis' techniques being the most popular. A different view of the results is shown in the right-hand column of Table 2, which displays the percentage of participants who indicated a level of use between moderate to high ( 3 to 5) for each technique. Evidently, the 'feasibility study' technique was highly used, whereas 
'depreciation methods' and 'payback period analysis' were reported as being of reasonable use by no more than 52 per cent of the respondents.

The 'Engineering Management' techniques were regarded as being of moderate to high average level of use by 60 per cent of the respondents. As can be seen from Table 3, 'forecasting' was, by far, the most popular technique in this category. If fact, 87 per cent of the respondents indicated a moderate to high use of 'forecasting'. 'SWOT analysis', 'project planning techniques', 'operations scheduling', and 'supply chain management' received average scores of between 3.1 and 3.5. The percentages of respondents who gave these techniques a score of 3 or more lied between 70 per cent and 78 per cent.

Table 1: t-tests of the difference in means between use and success, use of manufacturing and service sectors, and use of BSC and MSc holders

\begin{tabular}{|c|c|c|c|c|c|c|c|c|c|c|c|c|}
\hline \multirow{2}{*}{$\begin{array}{l}\text { Test } \\
\text { Categories }\end{array}$} & \multicolumn{4}{|c|}{ Use versus Success } & \multicolumn{4}{|c|}{ Average of Use } & \multicolumn{4}{|c|}{ Qualification/Degree } \\
\hline & कृ & 象 & $\omega$ & 2 & 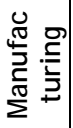 & 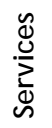 & $\downarrow$ & 2 & पू & $\sum$ & 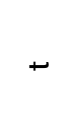 & 2 \\
\hline $\begin{array}{c}\text { Engineering } \\
\text { Management }\end{array}$ & 2.8 & 2.7 & 0.2 & 0.84 & 3.3 & 3.0 & 0.6 & 0.53 & 2.8 & 2.7 & 0.51 & 0.61 \\
\hline $\begin{array}{c}\text { Operation } \\
\text { Research }\end{array}$ & 1.0 & 1.1 & -0.3 & 0.75 & 1.3 & 1.2 & 0.2 & 0.87 & 0.9 & 1.2 & -0.83 & 0.413 \\
\hline $\begin{array}{c}\text { Quality \& } \\
\text { Engineering Stat. }\end{array}$ & 2.0 & 2.1 & -0.4 & 0.7 & 2.7 & 2.0 & 1.2 & 0.23 & 2.0 & 2.1 & -0.38 & 0.705 \\
\hline $\begin{array}{l}\text { Job Design } \\
\text { and Safety }\end{array}$ & 2.3 & 2.3 & -0.2 & 0.82 & 2.9 & 2.3 & 1 & 0.31 & 2.5 & 2.0 & 1.14 & 0.26 \\
\hline $\begin{array}{l}\text { Computer App. } \\
\& \text { Info. Systems }\end{array}$ & 2.7 & 2.8 & -0.4 & 0.71 & 2.6 & 2.8 & -0.3 & 0.8 & 2.6 & 2.7 & -0.27 & 0.786 \\
\hline $\begin{array}{c}\text { Engineering } \\
\text { Economy }\end{array}$ & 3.0 & 3.0 & -0 & 0.97 & 2.9 & 3.6 & -1.1 & 0.3 & 2.9 & 3.1 & -0.44 & 0.658 \\
\hline
\end{tabular}

The popularity of these techniques should not be surprising, as they are interrelated. In fact, they all pertain to strategies formulation and implementation. For example, 'forecasting' and 'SWOT analysis' are important techniques for strategy development, whereas 'project planning' is essential for the deployment of the initiatives adopted in the formulated strategies. The strategic objectives must be translated into operational targets, the attainment of which relies considerably on the use of techniques such as 'operations scheduling' and 'supply chain management'. The relatively low scores assigned to 'material requirement planning', 'inventory models', 'aggregate production planning', and 'just-intime' and 'lean production' may, in no small part, be attributed to the fact that the majority of the participants were working for service organisations where the use of such techniques is not in high demand. A surprising result was the low mean score associated with AHP and 'decision tree analysis'. In fact, the characteristics of the work undertaken by most of the participants, together with their organisational positions, indicate a frequent need for multi-criteria decision-making. Despite this, the survey revealed that the majority of them are more inclined to making decisions intuitively than to adopt a formal framework.

About 59 per cent of the participants rated the use of 'Computer Applications and Information Systems' as moderate to high. Table 4 shows that ERP received the highest mean score (3.8) for use. This is to be expected, considering that these systems were adopted in 78 per cent of the organisations for which the respondents work. This also explains the observation that 83 per cent of the participants indicated a moderate to high use of ERP. 'Database development methods' attained a similar level of use as 'computer programming'. 'Simulation', however, was associated with a low level of use, with its average score being 1.8. In fact, only 43 per cent of the participants rated its use as 
moderate to high. This is unfortunate, as 'simulation' is one of the most powerful techniques for designing, modelling, and evaluating complex systems.

Table 2: Average levels of use of the 'Engineering Economy' techniques

\begin{tabular}{cccc}
\hline No. & Techniques & $\begin{array}{c}\text { Avg. } \\
\text { Use }\end{array}$ & $\begin{array}{c}\% \text { of response } \\
\text { >=3 }\end{array}$ \\
\hline 1 & Feasibility Study & 3.4 & $75 \%$ \\
2 & Benefit-Cost Analysis & 3.1 & $65 \%$ \\
3 & Cash Flow Analysis & 3.1 & $67 \%$ \\
4 & Break Even Analysis & 3.0 & $63 \%$ \\
5 & Depreciation Methods & 2.7 & $52 \%$ \\
6 & Payback Period Analysis & 2.6 & $52 \%$ \\
\hline
\end{tabular}

Table 3: Average levels of use of the 'Engineering Management' techniques

\begin{tabular}{clll}
\hline No. & \multicolumn{1}{c}{ Techniques } & $\begin{array}{c}\text { Avg. } \\
\text { Use }\end{array}$ & $\begin{array}{c}\% \text { of response } \\
\text { >=3 }\end{array}$ \\
\hline 1 & Forecasting & 4.0 & $87 \%$ \\
2 & SWOT Analysis & 3.5 & $78 \%$ \\
3 & Project Planning & 3.4 & $73 \%$ \\
4 & Operation Scheduling & 3.1 & $65 \%$ \\
5 & Supply Chain Management & 3.1 & $70 \%$ \\
6 & ABC or Pareto Analysis & 3.0 & $65 \%$ \\
7 & Balanced Scorecard (BSC) & 3.0 & $67 \%$ \\
8 & Weighting and Scoring Models & 3.0 & $65 \%$ \\
9 & Material Requirement Planning & 2.8 & $54 \%$ \\
10 & Decision Tree Analysis & 2.6 & $65 \%$ \\
11 & Inventory Models & 2.5 & $52 \%$ \\
12 & Aggregate Production Planning & 2.1 & $48 \%$ \\
13 & J ust-in-Time and Lean Production & 1.8 & $35 \%$ \\
14 & Analytic Hierarchy Process (AHP) & 1.3 & $27 \%$ \\
\hline & & & \\
\hline
\end{tabular}

Table 4: Average use of the 'Computer Application and Information Systems' techniques

\begin{tabular}{clcc}
\hline No. & \multicolumn{1}{c}{ Techniques } & $\begin{array}{c}\text { Avg. } \\
\text { Use }\end{array}$ & $\begin{array}{c}\text { \% of response } \\
>=\mathbf{3}\end{array}$ \\
\hline 1 & Enterprise Resource Planning (ERP) & 3.8 & $83 \%$ \\
2 & Database Development Methods & 2.6 & $57 \%$ \\
3 & Computer Programming & 2.4 & $52 \%$ \\
4 & Simulation & 1.8 & $43 \%$ \\
\hline
\end{tabular}

The 'J ob Design and Safety' techniques were deemed to be of moderate to high use by 48 per cent of the respondents. As shown in Table 5, 'manpower planning' was the top-ranked technique, with 65 per cent of the participants characterising its use as being moderate to high. Due to its importance in matching employee abilities to current and future enterprise requirements, the popularity of this technique is understandable. 'Work measurement', which is one of the classic IE techniques, was ranked second in terms of use. The remaining 
techniques attained a comparable level of application. The low level of using techniques such as 'facilities planning models' and 'method study' is difficult to explain, considering their expected high demand in practice. This is also the case for 'accident causes analysis' and 'ergonomics and workplace design', which are supposed to feature a higher level of use, considering that many of the quality and safety certificates that the employers hold are pertinent to the application of these techniques.

Table 5: Average use of the 'J ob Design and Safety' techniques

\begin{tabular}{clcc}
\hline No. & \multicolumn{1}{c}{ Techniques } & $\begin{array}{c}\text { Avg. } \\
\text { Use }\end{array}$ & $\begin{array}{c}\text { \% of response } \\
\text { >=3 }\end{array}$ \\
\hline 1 & Manpower Planning & 3.0 & $65 \%$ \\
2 & Work Measurement (Time Study) & 2.4 & $52 \%$ \\
3 & Facilities Planning Models & 2.2 & $48 \%$ \\
4 & Method Study & 2.1 & $44 \%$ \\
5 & Accident Causes Analysis & 2.0 & $43 \%$ \\
6 & Ergonomics and Workplace Design & 2.0 & $38 \%$ \\
\hline
\end{tabular}

The majority (66 per cent) of the participants assigned an average level of use of 2 or less to the 'Quality and Engineering Statistics' techniques. As shown in Table 6, however, 78 per cent and 62 per cent of the participants reported a moderate to high use of 'check sheet' and 'sampling techniques', respectively. 'ISO systems implementation' was allotted a level of use score of 3 to 5 by 60 per cent of the respondents. This is in reasonably good agreement with the proportion of the ISO certified employers. It must be noted that there is an overlap between the techniques listed in Table 6, in the sense that some of them may be used individually or as part of another. For instance, 'check sheet' and 'cause and effect diagram' can be used separately or as tools in applying 'business process re-engineering'. However, it is also possible to use the latter exclusively. Therefore, it was necessary to distinguish the 13 techniques displayed in Table 6 from each other. This may also explain the similar average level of use that some of the quality techniques received. The limited application of 'total quality management' may be ascribed to the worldwide shift in emphasis to business excellence models [3].

Table 6: Average levels of use of the Quality and Engineering Statistics techniques

\begin{tabular}{clcc}
\hline No. & \multicolumn{1}{c}{ Techniques } & $\begin{array}{c}\text { Avg. } \\
\text { Use }\end{array}$ & $\begin{array}{c}\text { \% of response } \\
\text { >=3 }\end{array}$ \\
\hline 1 & Check Sheet & 3.7 & $78 \%$ \\
2 & Sampling Techniques & 2.8 & $62 \%$ \\
3 & ISO Systems Implementation & 2.7 & $60 \%$ \\
4 & Business Process Re-engineering & 2.5 & $54 \%$ \\
5 & Cause and Effect Diagram & 2.5 & $49 \%$ \\
6 & Total Quality Management & 2.3 & $51 \%$ \\
7 & Control Charts & 2.2 & $48 \%$ \\
8 & Regression and Correlation Analysis & 1.7 & $37 \%$ \\
9 & Design of Experiments & 1.1 & $24 \%$ \\
10 & Process Capability Analysis & 1.1 & $21 \%$ \\
11 & Hypothesis Testing & 1.1 & $25 \%$ \\
12 & Six Sigma & 1.1 & $22 \%$ \\
13 & Robust Design (Taguchi Methods) & 0.8 & $14 \%$ \\
\cline { 2 - 4 } & & &
\end{tabular}


Despite their applicability to a wide range of service and manufacturing contexts, 'control charts' were reported to be of significant use by no more than 48 per cent of the participants. Moreover, other statistical and quality control techniques such as 'regression and correlation analysis', 'process capability analysis', 'hypothesis testing', 'six sigma', and 'design of experiments' were not very popular. In fact, the limited use of experimental design may be due to the nature of the positions held by the participants and the type of work they do, which may involve no experimental work. It is also in line with the observed low level of use of 'simulation', which is a powerful tool for conducting experiments based on computer models. Taguchi's 'robust design' was the least-used quality technique, with its average score of 0.8 . This should not be surprising considering the moderate age of the Saudi industry and the fact that Taguchi suggested an advanced technique for robust product and process design - an activity that was rarely practised by the respondents in this study.

An interesting aspect that was also investigated was the difference in the mean levels of using quality techniques between participants who work for organisations certified according to ISO 9001:2008 and those who are employed by non-certified companies. The results of the t-test indicate that the null hypothesis of no difference should be rejected, as the $p$-value was 0.001 . In fact, in the certified companies, the average level of use was 4.24, which is noticeably larger than the 1.27 average observed in non-certified companies. This reflects the significant impact of ISO certification on improving the level of using quality techniques.

The 'Operations Research' techniques had very low level-of-use averages. In fact, they were shown to be of moderate to high use by no more than 22 per cent of the respondents. Contrary to the other IE groups, none of the nine techniques listed in Table 7 received an average use of 3 or even 2. Despite its effectiveness in solving resource allocation problems, 'linear programming' was deemed to be of moderate to high use by no more than 32 per cent of the respondents. A lower (but very close) percentage was attained by 'data envelopment analysis' and by 'queuing theory models'. While 'game theory' and 'goal programming' had the same level of use, the other techniques were rarely employed, as is evident from the very low $(<1)$ mean level of use.

A plausible reason for the low level of using 'Operations Research' techniques is the fact that its techniques are powerful for handling repetitive, well-defined operational problems. This feature has made possible the embedding of these techniques in many decision-support and ERP systems. It may be that a certain proportion of participants of this study were using many of the 'Operations Research' techniques through ERP systems without acknowledging or being aware of the adopted technique. For example, a typical application of 'linear programming' is the scheduling of pilots and stewards in the airline industry. However, this is commonly implemented by means of menu-driven ERP systems, where the user may not be familiar with the underpinning procedure. Worth noting here is that such systems were adopted in 78 per cent of the investigated organisations.

Another possible reason for the low levels of use of 'Operations Research' techniques pertains to the way in which its techniques are taught, which depends a great deal on the use of exercises with well-understood structures and, usually, a single correct solution. This contrasts with the open-ended real-life problems that can be dealt with in many different ways, rendering different possible solutions. The probable failure to recognise any resemblance between the textbook problems and those encountered in practice may be a maj or reason for the low levels of use not only of 'Operations Research' techniques but also of the other rarely employed ones.

\subsection{Perceived level of applicability in practice}

The intention here is to prioritise the assessed categories based on their applicability in practice, as seen by the participants. Table 8 shows the weights each category received based on the AHP analysis. As can be seen, 'Engineering Management' was regarded as incorporating the most applicable techniques, followed by 'Quality and Engineering 
Statistics' and 'Computer Application and Information Systems', which received almost the same weight. 'Engineering Economy', which involved the most applied techniques, came fourth in terms of perceived applicability, while 'J ob Design and Safety' came fifth. As was demonstrated empirically, 'Operations Research' was perceived as having the least applicable techniques.

Table 7: Average levels of use of the 'Operations Research' techniques

\begin{tabular}{clcc}
\hline No. & \multicolumn{1}{c}{ Techniques } & $\begin{array}{c}\text { Avg. } \\
\text { Use }\end{array}$ & $\begin{array}{c}\text { \% of response } \\
\text { >=3 }\end{array}$ \\
\hline 1 & Linear Programming & 1.4 & $32 \%$ \\
2 & Data Envelopment Analysis & 1.3 & $30 \%$ \\
3 & Queuing Theory Models & 1.2 & $29 \%$ \\
4 & Game Theory & 1.0 & $21 \%$ \\
5 & Goal Programming & 1.0 & $21 \%$ \\
6 & Nonlinear Programming & 0.9 & $17 \%$ \\
7 & Markov Analysis & 0.8 & $17 \%$ \\
8 & Integer Programming & 0.8 & $14 \%$ \\
9 & Dynamic Programming & 0.7 & $13 \%$ \\
\hline
\end{tabular}

Table 8: Applicability scores of IE categories' techniques based on AHP analysis

\begin{tabular}{clc}
\hline No. & \multicolumn{1}{c}{ Category } & Weight \\
\hline 1 & Engineering Management & 0.234 \\
2 & Quality and Engineering Statistics & 0.183 \\
3 & Computer Applications and Information Systems & 0.18 \\
4 & Engineering Economy & 0.173 \\
5 & Job Design and Safety & 0.119 \\
6 & Operations Research & 0.111 \\
\hline
\end{tabular}

Clearly, the results point to a gap between the perceived applicability and the practice or use of each of the IE techniques' groups. This implies that the participants did not consider as necessary the use of what they regard as applicable techniques. Surely perceiving a technique as applicable does not entail using it. To an extent, the perception of applicability is derived from one's ability to employ the technique. However, ability is a necessary but not sufficient condition for using a technique, as desire and suitability for the problem at hand are also needed.

\subsection{IE education and application barriers}

Of the participants, 25 per cent felt 'very satisfied' with their IE education, whereas 63 per cent were 'satisfied'. None of the respondents reported 'extreme dissatisfaction', while 12 per cent were 'not satisfied'. To explore this aspect further, the score representing the level of satisfaction was used as a dependent variable in a multiple regression model, with the predictors being the six levels of use averages attained by the IE categories' techniques. The intention was to determine the extent to which the satisfaction with IE education is related to the rate of using its techniques. The assumptions that underlie the use of regression - including the residuals' normality, constant variance, and independence - were examined, and no violation was noted. As none of the independent variables exerted a significant impact on the participants' satisfaction, it was concluded that their satisfaction is not affected by the level of using the taught techniques. 
The approaches that the participants adopt when dealing with practical problems were also investigated. They were asked which, from a list of four initiatives, they usually implement. Figure 3 portrays the results graphically. About 65 per cent of the participants indicated that they would try to find out how top organisations handle problems similar to the encountered one. Almost half of the respondents ( 45 per cent) reported that they revert to what was taught at the university. Of these, 10 per cent stated that they would also contact a consultant in the field. Moreover, 13 per cent asserted that they would use all of the above-mentioned three approaches. Sole reliance on what was taught at the university was only reported by 3 per cent of the participants, indicating that dealing with practical problems demands more than the knowledge presented in the IE programme.

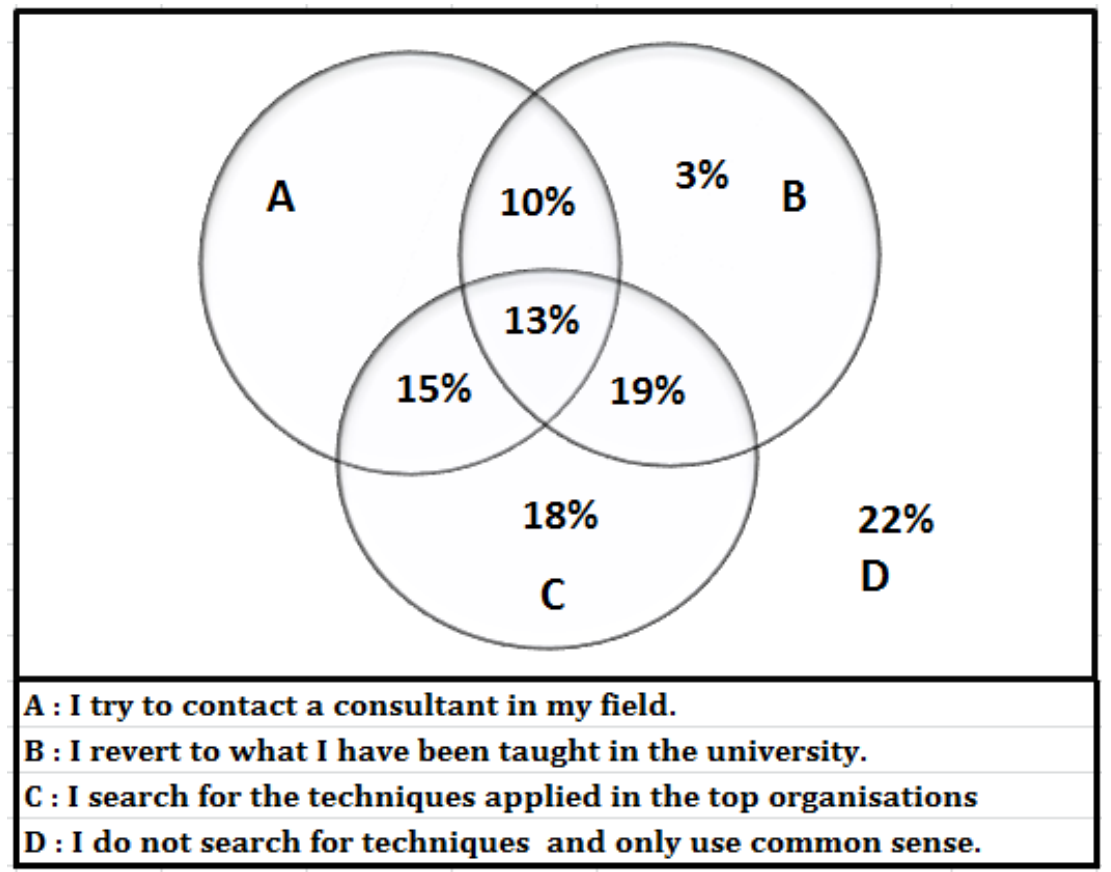

Figure 3: Approaches adopted by participants to deal with problems in practice

At the other end of the spectrum, 22 per cent of the respondents reported that they rely on common sense and do not use any of the afore-mentioned approaches. Considering that the IE jobs are, by and large, managerial, this is in reasonable agreement with the view of Mintzberg [5, 6] on the nature of managerial life - that it is full of meetings and interruptions, with limited time for conducting full rational analysis or applying formal techniques. Managers are thus forced to make their decisions quickly, based on intuition.

It is interesting to note that the participants who reported an exclusive reliance on what was taught in the university were recent graduates. This is not surprising, considering that they have little or no working experience to resort to when dealing with practical problems. On the other hand, the respondents who indicated that they only use common sense were the most senior ones (i.e., those who graduated during the period 2004-2006). The graduates with moderate working experience tend to adopt all of the approaches.

As a considerable proportion of the respondents reported a low level of use of IE techniques, it was interesting to determine why. A list of potential causes was given, and again respondents were asked to express their level of agreement on a Likert scale ranging from 1 (very weak) to 5 (very strong). As shown in Figure 4, limited contact with academics, the unrealistic nature of academic problems, and the complexity of practical problems, were seen as the most prevalent barriers to a wider use of IE techniques. 90 per cent, 89 per cent, and 84 per cent of respondents respectively reported a moderate to very strong 
agreement with these causes. Lack of on-the-job training and limited time for making decisions received an average agreement level of 3.5 and 3.2 respectively. Moreover, participants assigned the same average level endorsement (2.9) to the causes related to lacking 'know-how' and 'know-when' in using the studied IE techniques. In fact, about 65 per cent of the participants expressed a noticeable level of agreement with these causes. While 'know-how' pertains to the competence of the respondents in applying the surveyed techniques, 'know-when' relates to their ability to recognise the need to use any of the techniques when dealing with a practical problem. Inadequate management support was also regarded as a potential cause by 62 per cent of the respondents, while doubting the importance of the examined techniques was deemed an appreciable cause by no more than 37 per cent of the participants. Recognising the importance of the techniques by the maj ority of the participants, while not using them widely, is in agreement with the results of the perception levels of applicability analysis (section 3.3).

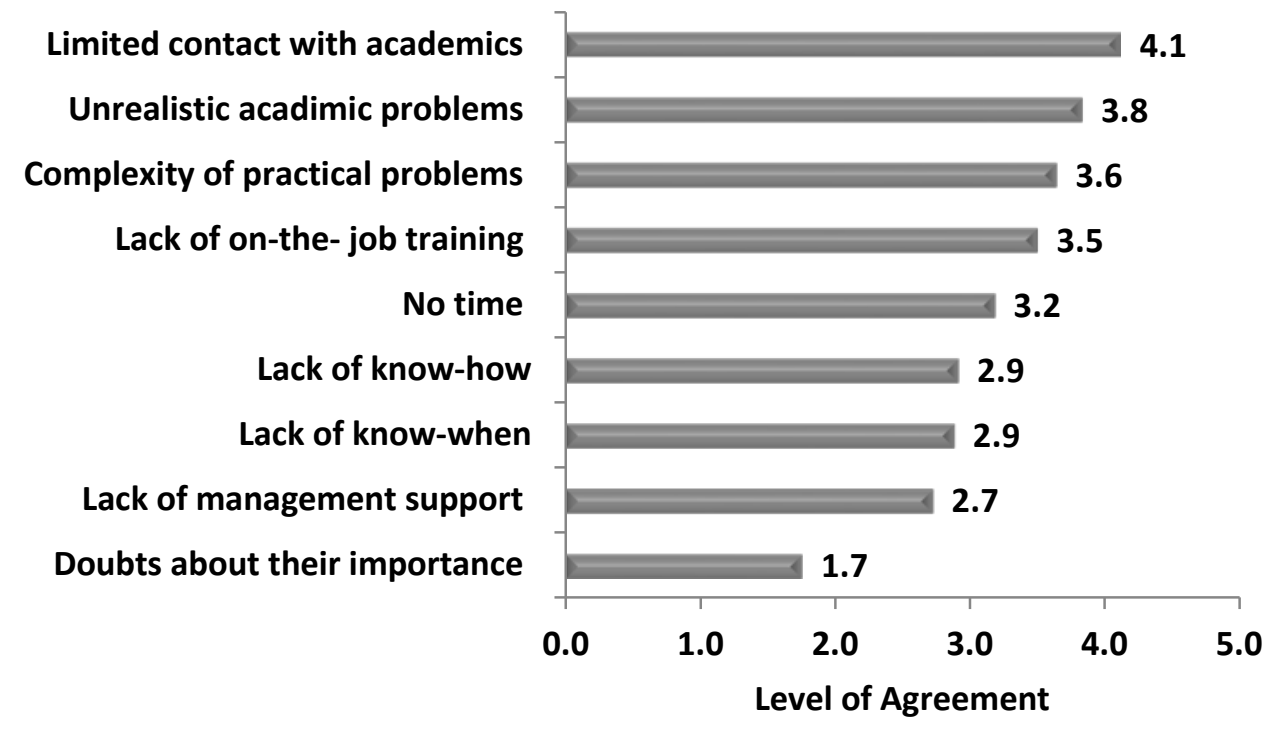

Figure 4: Agreement scores with the potential causes of the limited use of IE techniques

\section{CONCLUSIONS}

Research studies discussing the feedback of the alumni of an IE programme concerning their education are rarely reported in the literature. In this study, a survey was conducted to examine the gap between what is practised and what is taught in the IE programme at KAU. The main characteristics of the alumni's employers were discussed. It was found that the category 'Engineering Economy' involves the greatest practical application of techniques. On the other hand, 'Engineering Management' was perceived as incorporating the most applicable approaches. The limited use of IE techniques was mainly attributed to insufficient cooperation between practitioners and academics, and the simplistic nature of the problems addressed in universities compared with the more complex real-life problems.

In an effort to deal with some of the issues that this study has uncovered, the Department of IE at KAU is investigating the possibility of adopting a more practice-oriented curriculum where learning is driven by problems rather than by techniques. One approach that is under consideration is problem-based learning, where courses and topics are introduced with complex open-ended problems, the solutions of which dictate the knowledge and skills to be learned. The rationale is that learning in the context of problem-solving tends to instil in the students an appreciation of why they are learning what they are learning, and an ability 
to recognise when and how to apply the learned techniques. The department is also intending to review critically the current activities of its industry advisory board, and to engage its members in 'developing a curriculum' (DACUM) activities so that an IE programme is established that satisfies the needs of employers.

It is hoped that the adoption of these approaches will help the department's students to recognise and improve their learning process, thereby maintaining their relevance in the labour market through life-long learning.

\section{REFERENCES}

[1] Bryman, A. 2012. Social research methods, New York: Oxford University Press.

[2] Chapman, S. 2005. Research methods, Routledge, Oxford.

[3] Lo, Q.-Q. \& Chai, K.-H. 2012. Quantitative analysis of quality management literature published in total quality management and business excellence (1996-2010). Total Quality Management \& Business Excellence, 23 (5-6), pp. 629-651.

[4] McBurney, D.H. \& White, T.L. 2009. Research methods, Boston: Cengage Learning.

[5] Mintzberg, H. 2004. Managers, not MBAs: A hard look at the soft practice of managing and management development, San Francisco: Berrett-Koehler Publishers.

[6] Mintzberg, H. 2009. Managing, San Francisco:Berrett-Koehler Store.

[7] Rubin, A. \& Babbie, E.R. 2012. Brooks/Cole Empowerment Series: Essential research methods for social work, Boston: Cengage Learning.

[8] Saaty, T.L. 1994. Fundamentals of decision making and priority theory: With the analytic hierarchy process, Pittsburgh: RWS Publications.

[9] Saaty, T.L. 1990. Multicriteria decision making: The analytic hierarchy process: Planning, priority setting resource allocation, Pittsburgh: RWS Publications.

[10] Turner, W.C., Mize, J.H., Case, K.E. \& Nazemetz, J.W. 1992. Introduction to industrial and systems engineering, New J ersey: Prentice-Hall. 